\title{
Effect of oxytocin and seminal plasma treatment on uterine contractile activity and pregnancy rates in subfertile mares
}

\author{
Ute Pansegrau', Sabine Meinecke-Tillmann², Jan-Hein Swagemakers' ${ }^{7}$ und Burkhard Meinecke² \\ Veterinary Clinic for Horses, Lüsche' ${ }^{1}$ and Department of Reproductive Biology, University of Veterinary Medicine Foundation, Hannover², Germany
}

\begin{abstract}
Summary
The aim of the study was to find out how reproductive disorders in problem mares, with a disposition to persistent mating induced endometritis, are related to dysfunctional uterine contractile activity (UCA). Additionally, seminal plasma, given into the uterus after insemination, and oxytocin administered immediately after insemination, were tested on their stimulating effects on uterine contractions and influence on pregnancy rates. Also the influence of UCA on uterine bacteriological and cytological findings before and after insemination was examined. The subfertile mares were inseminated into the uterine body $24 \mathrm{~h}$ and $48 \mathrm{~h}$ after $\mathrm{hCG}$-administration and were treated immediately after Al with oxytocin (Group 1, $\mathrm{n}=27$ cycles) or additional seminal plasma (Group 2, $\mathrm{n}=25$ cycles) or were left untreated (Group $3, n=30$ cycles) after Al. Group 4 (healthy mares with foal, $n=12$ cycles) was inseminated twice without further treatment and served as control. UCA was evaluated by transrectal ultrasonography 16 to 18 days after last estrus, before and after the first and second Al and $48 \mathrm{~h}$ after the second $\mathrm{Al}$. Contractions were documented in a score-level-system (0-IV). Bacteriological and cytological samples were taken before the first and $48 \mathrm{~h}$ after the second Al. A uterine biopsy was analysed in interestrus before insemination. Significant differences in the UCA of the total group of mares were obtained between the different times of evaluation. Comparing the 4 treatment groups, the fertile control group showed in general stronger uterine contractions than the other groups. UCA between the fertile control and the oxytocin treated mares on the one side and the seminal plasma and untreated mares on the other side differed significantly. A positive correlation was shown between UCA and pregnancy results. The pregnancy rates differed significantly between the fertile control group (83\%) and the 3 experimental groups ( $40 \%$ ). There was no correlation between UCA and the results of the bacteriological and cytological samples of the endometrium. But there was a significant relationship between the results of the cytological sample obtained $48 \mathrm{~h}$ after the second insemination and the pregnancy results. Because of the positive correlation between UCA and pregnancy rate, poor uterine contractions are seen as one of the major causes of subfertility in mares. The present study demonstrated that uterine contractions are stimulated by artificial insemination and that consecutive inseminations even intensified uterine contractions. Barren mares showed in general a lower UCA than fertile mares did. To obtain good pregnancy results, also negative cytological swabs $48 \mathrm{~h}$ after insemination were important, since mares with positive results at this time had a minor chance of becoming pregnant. Based on these results optimal insemination frequency and way and time of uterine sampling should be discussed in the management of broodmares.
\end{abstract}

Keywords: mare, uterine contractions, seminal plasma, oxytocin, pregnancy rate

Einfluss einer Oxytocin- oder Seminalplasmabehandlung auf die uterine Kontraktionsaktivität und die Trächtigkeitsrate bei subfertilen Stuten

Ziel der Untersuchung war es, herauszufinden inwiefern sich Reproduktionsstörungen bei Problemstuten, die zu besamungsinduzierter Endometritis neigen, auf eine gestörte Kontraktionsaktivität der Gebärmutter zurückführen lassen. Zusätzlich sollte überprüft werden ob mit Seminalplasma eine ähnliche kontraktionsstimulierende Wirkung wie mit Oxytocin erreicht werden kann, und ob sich diese Behandlung direkt post inseminationem positiv auf die Trächtigkeitsrate auswirkt. Des Weiteren wurde untersucht, ob die Uteruskontraktionsaktivität die uterinen mikrobiologischen und zytologischen Befunde prae und post inseminationem beeinflusst. Für die Studie standen 62 Warmblutstuten zur Verfügung, die in insgesamt 94 Zyklen untersucht wurden. Dabei entfielen 12 Stuten mit Fohlen bei Fuß mit jeweils einem Zyklus auf die fertile Kontrollgruppe 4. Die restlichen 50 Stuten, die in der letzten Decksaison güst geblieben waren, wurden in insgesamt 82 Zyklen untersucht und zufällig auf die drei Versuchsgruppen: Oxyłocin (Gruppe 1, n = 27 Zyklen), Seminalplasma (Gruppe 2, n = 25 Zyklen) und unbehandelt (Gruppe 3, $\mathrm{n}=30$ Zyklen) aufgeteilt. Alle Stuten wurden mit Frischsamen zweier fertiler Hengste terminiert, 24 und $48 \mathrm{~h}$ nach hCG-Gabe, besamt. Je nach Versuchsgruppe wurde den Stuten direkt nach der Besamung 20 IE Oxytocin injiziert, 20 ml Seminalplasma aus einem Seminalplasmapool intrauterin verabreicht oder sie blieben unbehandelt. Die uterine Kontraktionsaktivität wurde mittels transrektaler Ultrasonographie am Tag 16-18 nach der letzten Rosse, direkt vor und nach der ersten und zweiten Insemination, sowie $48 \mathrm{~h}$ nach der zweiten Besamung bestimmt. Dazu wurde die Ultraschallsonde quer über das Uterushorn ipsilateral zum dominanten/ovulierten Follikel positioniert und die Gebärmutterkontraktionen über 5, bzw. 10 Minuten nach der ersten Besamung, erfasst. Die Auswertung der Kontraktionsaktivität erfolgte mit Hilfe eines Scoresystems von 0 (keine Kontraktionen) bis IV (sehr starke Kontraktionen). Zusätzlich wurde von allen Stuten im Interöstrus ein Endometriumsbioptat gewonnen, sowie vor der ersten und $48 \mathrm{~h}$ nach der zweiten Besamung Uterustupferproben für eine mikrobiologische und zytologische Auswertung genommen. Die Ergebnisse zeigten, dass ein Vergleich der mittleren uterinen Kontraktionsaktivität aller Stuten deutliche Unterschiede zwischen fast allen Messzeitpunkten ergab. Nach der zweiten Insemination war zusätzlich eine hochsignifikant stärkere uterine Kontraktionsaktivität zu verzeichnen als nach der ersten Besamung. Beim Vergleich der myometrialen Aktivität zwischen den Gruppen, zeigte die Kontrollgruppe ein allgemein höheres Aktivitätsniveau. Signifikante Unterschiede zwischen den Gruppen ließen sich zum Zeitpunkt 16 bis 18 Tage nach der letzten Besamung zwischen der Kontrollgruppe und allen Versuchsgruppen, zum Zeitpunkt nach der ersten Besamung zwischen der Oxyłocin- und der Kontrollgruppe auf der einen und der Seminalplasma- und der unbehandelten Gruppe auf der anderen Seite darstellen. Nach der zweiten Insemination zeigte die Oxytocingruppe signifikant stärkere Kontraktionen als die Seminalplasma- und die unbehandelte Gruppe, die Kontrollgruppe aber nur noch gegenüber der unbehandelten Gruppe. Die Kontraktionsaktivität der Gebärmutter in der Seminalplasma- und der unbehandelten Gruppe 
unterschied sich zu keinem Zeitpunkt signifikant voneinander. Außerdem konnte zwischen der Uteruskontraktionsaktivität und dem Trächtigkeitsergebnis ein positiver Zusammenhang gezeigt werden. Das Ergebnis der Trächtigkeitsuntersuchung unterschied sich signifikant zwischen der Kontrollgruppe (83 \%) und den Versuchsgruppen (40 \%). Es konnte aber kein Zusammenhang zwischen der Uterusmotilität und den Ergebnissen der mikrobiologischen und zytologischen Untersuchung der Gebärmutter gebildet werden. Allerdings konnte ein signifikanter Zusammenhang zwischen der $48 \mathrm{~h}$ nach der Besamung erhobenen zytologischen Probe und dem Ergebnis der Trächtigkeitsuntersuchung hergestellt werden. Da ein positiver Zusammenhang zwischen der Kontraktionsaktivität und dem Trächtigkeitsergebnis festgestellt werden konnte, ist eine verringerte uterine Aktivität als eine Ursache von suboptimaler Fertilität bei Stuten zu sehen. Die Uterusmotilität wurde durch die Besamung angeregt und steigerte sich bei aufeinanderfolgenden Besamungen noch signifikant. Bei subfertilen Stuten war generell eine geringere Myometriumsaktivität feststellbar. Hinsichtlich eines positiven Trächtigkeitsergebnisses war auch der Nachweis von PMNen im Uterus $48 \mathrm{~h}$ nach der Besamung von Bedeutung. Stuten mit einem positiven zytologischen Tupfer zu diesem Zeitpunkt hatten die geringsten Trächtigkeitschancen.Daher sollte über eine optimale Besamungsfrequenz und die Art und den Zeitpunkt der Probennahme aus der Gebärmutter nachgedacht werden.

Schlüsselwörter: Stute, Uteruskontraktionen, Oxyłocin, Seminalplasma, Trächtigkeitsrate, Reproduktion

\section{Introduction}

Uterine contractions play an active role in sperm transport across the female genital tract (Katila et al. 2000) and in elimination of fluid accumulations from the uterus during estrus or after breeding (Troedsson et al. 1995). They cause the embryonal movement through the uterus between day 6 and 16 of pregnancy (Leith and Ginther 1985) and finally they are necessary for labour during parturition (Haluska et al. 1987). Also during the progress of the cycle a transient UCA (uterine contractile activity) could be recognized (Griffin and Ginther $1990,1993)$. Methods of UCA evaluation in the horse are transrectal palpation of the uterus (Griffin et al. 1992), electromyography (Jones et al. 1991), evaluation of uterine pressure (Cadario et al. 1999), scintigraphy (Katila et al. 2000) or transrectal ultrasonography in $\mathrm{M}$ - (Campbell and England 2002, 2004) or B-mode (Griffin and Ginther 1990, 1993, Nikolakopoulus and Watson 2002, Portus et al. 2005).

Previous studies showed that insemination or breeding stimulated myometrial activity in the mare (Troedsson et al. 1998, Campbell and England 2003, 2006). Katila et al. (2000) found spermatozoa in the tip of the uterine horn 8 min after insemination, and Bader (1982) isolated sperm cells from the oviduct as fast as $2 \mathrm{~h}$ after breeding. Subfertile mares are supposed to have an impaired UCA after insemination and are not able to clear the uterus from inflammation after breeding. A transient inflammatory response after breeding is a physiological reaction of the mare's genital tract to insemination (Katila 1995, Troedsson et al. 1995). Polymorphonuclear neutrophils (PMN) were found in the uterus 30 min after insemination. The inflammatory reaction peaked at $8 \mathrm{~h}$ and 24 to $48 \mathrm{~h}$ after breeding almost all PMNs were gone from the uterus (Katila 1995). If mares are not able to clear the uterus from inflammation within $96 \mathrm{~h}$ they are classified as susceptible to persistent mating induced endometritis (Troedsson et al. 1995). Kotilainen et al. (1994) discovered that sperm cells are the major cause for post breeding endometritis and induce the influx of PMNs into the uterus. Troedsson et al. (1998) and Dahms and Troedsson (2002) showed that seminal plasma was able to suppress uterine immune reaction against spermatozoa in vitro. But in in vivo studies seminal plasma induced a stronger uterine inflammatory reaction than normal semen extenders or saline did (Quetin 2001, Fiala et al. 2002, Palm et al. 2006).

The aim of the present study was to investigate the correlation between UCA before and after insemination and a possibly impaired uterine clearance after insemination in subfertile mares in comparison to fertile ones, as well as the effect of two successive inseminations during one estrus on UCA. Furthermore, the influence of additional seminal plasma and oxytocin on myometrial activity after insemination was studied. Results were analyzed in relation to the effects of treatment on uterine bacteriological and cytological samples and on pregnancy rates.

\section{Materials and Methods}

Mares

The examination took place at a private stud farm in Northwestern Germany. During the study period between February and August the mares were housed in individual boxes, fed with oats and hay and went on pasture daily.

A total of 62 warmblood mares (age 4 to 21 , mean age 12 years) in good body condition were examined in 94 cycles. Twelve of the 62 mares, with one cycle each, were mares with foal (age 6 to 12, mean age 9 years) with no history of reproductive disorders. They served as fertile control group. The other 50 subfertile, barren mares (age 4 to 21 , mean age 13 years) were examined in 82 cycles and randomly assigned into three experimental groups: Group 1 received oxytocin' after insemination ( $\mathrm{n}=27$ cycles, 20 IU oxytocin). In Group 2 seminal plasma was given into the uterine lumen at the time of insemination $(\mathrm{n}=25$ cycles, $20 \mathrm{ml}$ seminal plasma from a deep frozen seminal plasma pool), and Group 3 was left untreated ( $n=30$ cycles). Every mare was inseminated twice into the uterine body with fresh semen $\left(500 \times 10^{6}\right.$ spermatozoa, $12 \mathrm{ml}$ insemination volume, egg yolk extender) of one of two fertile stallions 24 and $48 \mathrm{~h}$ after $\mathrm{hCG}^{2}$ administration (2500 IU hCG i.v.).

Mares were examined the first time on day 16 to 18 of the cycle (interestrus preceeding insemination) by rectal palpation and ultrasonography $\left(6,0 \mathrm{MHz}\right.$ linear-transducer $\left.{ }^{3}\right)$ to determine the stage of cycle and the corresponding uterine contractile activity (UCA1). Afterwards a uterine biopsy sample was obtained. When the mares showed signs of estrus behaviour and the dominant follicle had reached a diameter of at least $35 \mathrm{~mm}$, they were treated with 2500 IU hCG i.v. to cause ovulation within $48 \mathrm{~h}$. The first insemination followed $24 \mathrm{~h}$ after hCG administration. Immediately before and 
after insemination (and treatment in the oxytocin and the seminal plasma group) UCA was evaluated (UCA2 and $3 a$ and b). Also directly before insemination, but after evaluation of the UCA, uterine swabs were taken for bacteriological and cytological investigation (guarded culture swabs ${ }^{4}$ ). A second insemination was carried out $48 \mathrm{~h}$ after hCG administration, and again UCA (UCA4 and 5) was evaluated immediately before and after insemination (and treatment in the oxytocin and the seminal plasma group). Forty-eight hours after the second insemination uterine contractions were determined once more (UCA6) and uterine bacteriological and cytological samples were obtained immediately afterwards. Sixteen to 18 days after the second insemination all mares were examined ultrasonically to determine pregnancy rates.

\section{Uterine contractile activity}

Uterine contractile activity was evaluated by transrectal Bmode ultrasonography $(6.0 \mathrm{MHz}$ linear-transducer) seven times per mare (UCA 1 - 6, see above). The ultrasound probe was fixed in a transverse position over the uterine horn ipsilaterally to the dominant/ovulated follicle. In each case uterine contractions were recorded and videotaped over periods of 5 min (UCA 1,2, 4 - 6), respectively, and for a $10 \mathrm{~min}$ period after the first insemination (UCA $3 a, b)$. The strength of uterine contractile activity was documented in a score level system $(0=$ no contractions to $\mathrm{IV}=$ very strong, frequent contractions). During the time of examination the mares were not sedated to avoid an influence of $\alpha 2$-agonists on uterine motility. The scans were videotaped and analysed without knowledge of group at the end of the study. Only periods without interference of intestinal motility were used for evaluation.

\section{Uterine sampling}

For further comparison between the groups endometrial biopsies were taken 16 to 18 days after the estrus preceeding the present investigation. Bacteriological and cytological swabs of the uterus were obtained before the first and $48 \mathrm{~h}$ after the second insemination. Uterine biopsies were fixed in $4 \%$ formalin and were sent to the Department of Pathology, University of Veterinary Medicine Hannover, for histological examination and histopathological categorisation according to Kenney and Doig (1986).

The bacteriological samples were incubated at $37^{\circ} \mathrm{C}$ on Columbia blood agar ${ }^{5}$, Columbia-CAP agar ${ }^{5}$, Gassner agar ${ }^{5}$ und Sabouraud-Glucose agar ${ }^{5}$ for $48 \mathrm{~h}$. Every $24 \mathrm{~h}$ the agars were checked for bacterial growth. If bacterial growth was evident, bacteria were determined and the samples were classified as bacteriologically positive or negative as described by Busch and Klug (1999).

For the cytological samples the swab was rolled on a clean, dry glass slide, air dryed, heat fixed and stained by the Pappenheim method. The examination for polymorphonuclear leucocytes was done according to Brook (1984). Ten visual fields per slide were evaluated at a magnification of 400x and the findings were categorised.

\section{Statistical analyses}

Statistical analyses were performed with the SPPS Base 10.0 program $^{6}$ and with the SAS program ${ }^{7}$. Significance was set at $P \leq 0.05$. The comparison of uterine contractile activtiy between the different times of measurements was done with the paired t-test. Student's t-test was used for the comparison of the uterine contractions between the different experimental groups. Pregnancy rates, influence of biopsy on pregnancy results and the comparison of first and second bacteriological and cytological sample were analyzed with the Chi-squared test. Influence of bacteriological and cytological samples on outcome of pregnancy results and influence of the different group treatments on bacteriological and cytological results were calculated with the Fisher's exact test. For the evaluation of the influence of UCA on pregnancy results a hierarchical cluster analysis and analysis of variance was performed and Pearson coefficient of correlation was calculated.

\section{Results}

Significant differences in UCA were recognized within the total group of mares between the particular times of evaluation (UCA1 vs. UCA2 - 6: P $\leq 0.002$; UCA2 and 4 vs. UCA3 and 5: $P \leq 0.0001$; UCA3 and 5 vs. UCA6 ( $\leq \leq 0.002)$. Additionally, UCA after the second insemination was highly significantly stronger than after the first insemination (UCA3 vs. UCA5: $P \leq 0.0001$ ), although score levels before inseminations were similar (see Figure 1 and Table 1).

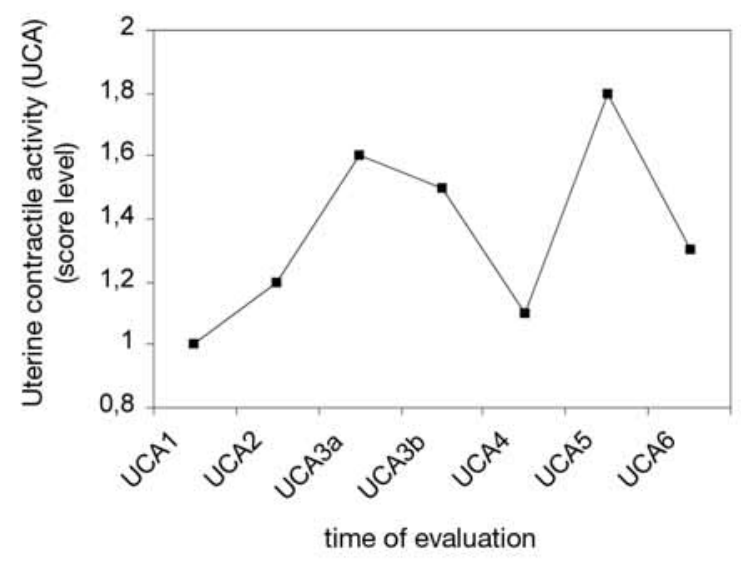

- Mean score level of all groups

Fig 1 Mean score levels of UCA in the total group of 62 mares in $\mathrm{n}=94$ cycles on the different times of evaluation. UCA on day 16 to 18 after last estrus (UCA1), UCA before first AI (UCA2), UCA after first IA (first 5 out of 10 min) (UCA3a), UCA after first IA (second 5 out of $10 \mathrm{~min}$ ) (UCA3b), UCA before second IA (UCA4), UCA after second IA (UCA5), UCA $48 \mathrm{~h}$ after second IA (UCA6)

Verlauf der mittleren Scorewerte der Kontraktionsaktivität aller 62 Stuten in $n=94$ Zyklen zu den einzelnen Messzeitpunkten. Kontraktionsmessung 16-18 Tage nach der letzten Rosse (UCA1), Kontraktionsmessung vor der ersten Besamung (UCA2), Kontraktionsmessung nach der ersten Besamung (erste 5 Minuten) (UCA3a), Kontraktionsmessung nach der ersten Besamung (zweite 5 Minuten) (UCA3b), Kontraktionsmessung vor der zweiten Besamung (UCA4), Kontraktionsmessung nach der zweiten Besamung (UCA5), Kontraktionsmessung $48 \mathrm{~h}$ nach der zweiten Besamung (UCA6). 
Table 1 UCA in the total group of mares: Significant differences between the different times of evaluation. ${ }^{*}=\mathrm{P} \leq 0,05,{ }^{* *}=\mathrm{P} \leq$ $0,01,{ }^{* * *}=P \leq 0,001$, UCA on day 16 to 18 after last estrus (UCA1), UCA before first Al (UCA2), UCA after first IA (first 5 out of $10 \mathrm{~min}$ ) (UCA3a), UCA after first IA (second 5 out of $10 \mathrm{~min}$ ) (UCA3b), UCA before second IA (UCA4), UCA after second IA (UCA5), UCA 48 h after second IA (UCA6).

Uterine Kontraktionsaktivität bei Betrachtung der Gesamtgruppe: Signifikante Unterschiede zwischen den einzelnen Messzeitpunkten. Kontraktionsmessung 16-18 Tage nach der letzten Rosse (UCA1), Kontraktionsmessung vor der ersten Besamung (UCA2), Kontraktionsmessung nach der ersten Besamung (erste 5 Minuten) (UCA3a), Kontraktionsmessung nach der ersten Besamung (zweite 5 Minuten) (UCA3b), Kontraktionsmessung vor der zweiten Besamung (UCA4), Kontraktionsmessung nach der zweiten Besamung (UCA5), Kontraktionsmessung $48 \mathrm{~h}$ nach der zweiten Besamung (UCA6).

\begin{tabular}{|c|c|c|c|c|c|c|c|}
\hline \multicolumn{8}{|c|}{ Evaluation times of uterine contractile activity (UCA) } \\
\hline & UCA 1 & UCA2 & UCA3a & UCA3b & UCA4 & UCA5 & UCA6 \\
\hline \multicolumn{8}{|l|}{ UCAl } \\
\hline UCA2 & $* * *$ & & & & & & \\
\hline UCA3a & $* * *$ & $* * *$ & & & & & \\
\hline UCA3b & $* * *$ & $* * *$ & & & & & \\
\hline UCA4 & $*$ & & $* * *$ & $* * *$ & & & \\
\hline UCA5 & $* * *$ & $* * *$ & $* * *$ & $* * *$ & $* * *$ & & \\
\hline UCA6 & $* * *$ & & $* * *$ & * & & $* * *$ & \\
\hline
\end{tabular}

Comparing the 4 treatment groups among each other, the fertile control group showed in general stronger uterine contractions. Significant differences between the groups were seen between the control group and all other groups at the first evaluation on day 16 to 18 of the cycle preceeding insemination (UCA1: $P \leq 0.02$ ), and between the control and the oxytocin group on the one side and the seminal plasma and untreated mares group on the other side after the first insemination (UCA3: $P \leq 0.0001$ ). After the second insemination significantly stronger uterine contractions were realized in the oxytocin group in contrast to the seminal plasma and the untreated group (UCA5: P $\leq$ 0.05), while the control group had only significantly stronger contractions than the untreated group (UCA5: $P \leq 0.05)$. The UCA between the seminal plasma and the untreated group differed at no time significantly. Mean score levels of UCA in the different groups of mares during the diverse periods of investigation are shown in Figure 2 and Table 2.
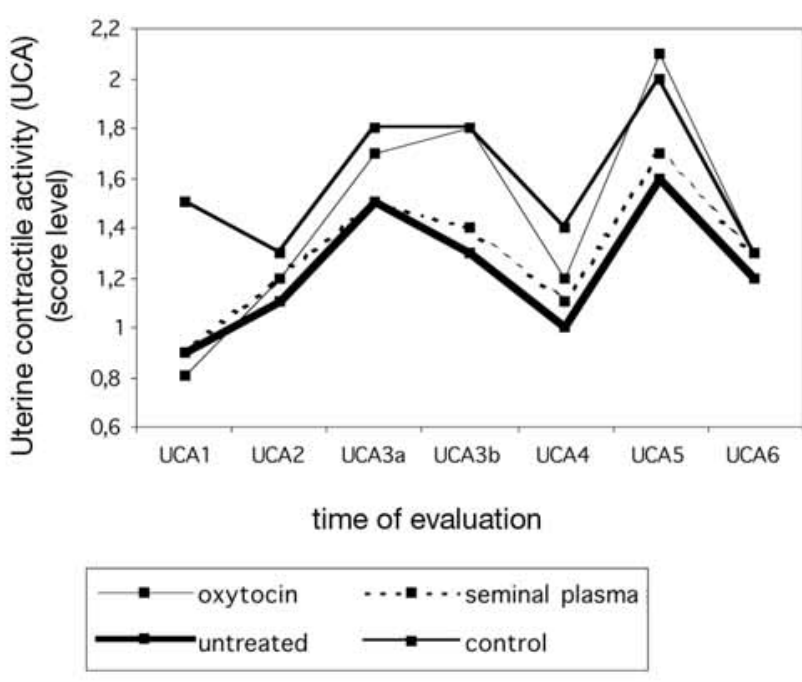

Fig 2 Mean score levels of UCA in the different groups on different times of evaluation. UCA on day 16 to 18 after last estrus (UCA1), UCA before first AI (UCA2), UCA after first IA (first 5 out of $10 \mathrm{~min}$ ) (UCA3a), UCA after first IA (second 5 out of $10 \mathrm{~min}$ ) (UCA3b), UCA before second IA (UCA4), UCA after second IA (UCA5), UCA $48 \mathrm{~h}$ after second IA (UCA6).

Mittlere Scorewerte der Uteruskontraktionsaktivität in den verschiedenen Gruppen zu den einzelnen Messzeitpunkten. Kontraktionsmessung 16-18 Tage nach der letzten Rosse (UCA1), Kontraktionsmessung vor der ersten Besamung (UCA2), Kontraktionsmessung nach der ersten Besamung (erste 5 Minuten) (UCA3a), Kontraktionsmessung nach der ersten Besamung (zweite 5 Minuten) (UCA3b), Kontraktionsmessung vor der zweiten Besamung (UCA4), Kontraktionsmessung nach der zweiten Besamung (UCA5), Kontraktionsmessung 48 h nach der zweiten Besamung (UCA6).

A positive correlation was shown between UCA and pregnancy results, while there was no relationship between UCA and the results of the bacteriological and cytological samples of the endometrium.

The comparison of the two bacteriological and cytological samples obtained prior to the first and $48 \mathrm{~h}$ after the second insemination showed no significant differences. Prior to first breeding $54 \%$ of the bacteriological and $47 \%$ of the cytological samples were negative, and $48 \mathrm{~h}$ after second insemination $56 \%$ of the bacteriological and $64 \%$ of the cytologi-

Table 2 Mean score levels of UCA in the different groups on different times of evaluation. UCA on day 16 to 18 after last estrus (UCA1), UCA before first AI (UCA2), UCA after first IA (first 5 out of $10 \mathrm{~min}$ ) (UCA3a), UCA after first IA (second 5 out of $10 \mathrm{~min})$ (UCA3b), UCA before second IA (UCA4), UCA after second IA (UCA5), UCA 48 h after second IA (UCA6). Different superscript letters (a, b, c) within the same column are stastically different $(\mathrm{P} \leq 0,05)$.

Mittlere Scorewerte der Uteruskontraktionsaktivität in den verschiedenen Gruppen zu den einzelnen Messzeitpunkten. Kontraktionsmessung 16-18 Tage nach der letzten Rosse (UCA1), Kontraktionsmessung vor der ersten Besamung (UCA2), Kontraktionsmessung nach der ersten Besamung (erste 5 Minuten) (UCA3a), Kontraktionsmessung nach der ersten Besamung (zweite 5 Minuten) (UCA3b), Kontraktionsmessung vor der zweiten Besamung (UCA4), Kontraktionsmessung nach der zweiten Besamung (UCA5), Kontraktionsmessung 48 h nach der zweiten Besamung (UCA6). Verschiedene hochgestellte Buchstaben $(a, b, c)$ innerhalb der gleichen Spalte kennzeichnen statistisch signifikante unterschiedliche Werte.

\begin{tabular}{cccccccc}
\hline \multirow{2}{*}{ Group } & \multicolumn{7}{c}{ Evaluation times of uterine contractile activity (UCA) } \\
\cline { 2 - 7 } & UCA1 & UCA2 & UCA3a & UCA3b & UCA4 & UCA5 & UCA6 \\
\cline { 2 - 7 } Oxytocin & $0.8^{\mathrm{b}} \pm 0.6$ & $1.2 \pm 0.7$ & $1.7 \pm 0.6$ & $1.8^{\mathrm{a}} \pm 0.6$ & $1.2 \pm 0.7$ & $2.1^{\mathrm{a}} \pm 0.5$ & $1.3 \pm 0.8$ \\
Seminal plasma & $0.9^{\mathrm{b}} \pm 0.6$ & $1.2 \pm 0.6$ & $1.5 \pm 0.5$ & $1.4^{\mathrm{b}} \pm 0.6$ & $1.1 \pm 0.6$ & $1.7^{\mathrm{bc}} \pm 0.6$ & $1.3 \pm 0.6$ \\
untreated & $0.9^{\mathrm{b}} \pm 0.6$ & $1.1 \pm 0.5$ & $1.5 \pm 0.5$ & $1.3^{\mathrm{b}} \pm 0.6$ & $1.1 \pm 0.6$ & $1.6^{\mathrm{c}} \pm 0.5$ & $1.2 \pm 0.7$ \\
Control & $1.5^{\mathrm{a}} \pm 0.5$ & $1.3 \pm 0.5$ & $1,8 \pm 0.5$ & $1.8^{\mathrm{a}} \pm 0.5$ & $1.4 \pm 0.5$ & $2.0^{\mathrm{ab}} \pm 0.5$ & $1.3 \pm 0.7$ \\
\hline
\end{tabular}


cal swabs showed negative results. Comparison of the treatment groups among each other showed significantly less positive bacteriological samples $48 \mathrm{~h}$ after the second insemination in the oxytocin group than in the seminal plasma treated group $(P=0.02)$. In every group lower numbers of polymorphonuclear neutrophils were recognized $48 \mathrm{~h}$ after the second insemination than in the cytological samples before the first breeding. The same was true for bacteriological findings, except for the seminal plasma group.

A significant relationship $(P \leq 0.0001)$ between the results of the cytological sample obtained $48 \mathrm{~h}$ after the second insemination and the pregnancy results was recognized. In $79 \%$ of the non-pregnant mares uterine cytological samples were classified as positive $48 \mathrm{~h}$ after insemination, while $60 \%$ of the pregnant mares had negative cytological samples at the matching time.

Uterine biopsy classification was not related with pregnancy results in this study. Pregnancy rates differed significantly $(P \leq$ $0.05)$ between the control group (83\%) and the 3 experimental groups (40\%).

\section{Discussion}

In the present study the uterine contractile activity was evaluated seven times per cycle: 16 to 18 days after the estrus preceeding insemination, immediately before and after the first and second insemination as well as $48 \mathrm{~h}$ after the second insemination. The chosen times of examination permitted a good long-term overview on myometrial activity before and after estrus and before and after successive inseminations. Earlier studies showed either the development of uterine contractions in different stages of the cycle (Griffin and Ginther 1990,1993 ) or evaluated the uterine contractile activity prior and over different time periods after a single insemination (Troedsson et al. 1998, Campbell and England 2003, Sinnemaa et al. 2005).

Uterine contractile activity was evaluated by transrectal Bmode ultrasonography. The ultrasound probe was fixed in a transverse position over the uterine horn ipsilaterally to the dominant/ovulated follicle. In each case uterine contractions were recorded and videotaped over periods of $5 \mathrm{~min}$, respectively, and for a $10 \mathrm{~min}$ period after the first insemination. Unlike electromyography, uterine pressure measurement and scintigraphy, this method of evaluation is practically not invasive and can also be done under field conditions. Nikolakopoulos and Watson (2002) demonstrated also that transrectal manipulation did not change uterine contractile activity or oxytocin and PGF2 $\alpha$ plasma levels during scanning. Additionally, to minimize environmental stimuli, mares were not sedated during time of measurements, because of the stimulating effect of $\alpha 2$-agonists on myometrial activity. Schatzmann et al. (1994) and Gibbs and Troedsson (1995) showed that $\alpha 2$-agonists like xylazine, detomedine and romfenidine stimulated uterine contractile activity in mares.

For the evaluation of the uterine contractions a score level system like in studies of Cross and Ginther (1988) (score level from 0 to 4) and Nikolakopoulos and Watson (2002) (score level from 0 to 10) was used. Evaluation of uterine contrac- tions made with B-mode ultrasonography is not as clear as in the $M$-mode technique, where contractions are shown with amplitude, duration and frequency on a graph of motion (Campbell and England 2002), but in the present study we tried to get an objective view on myometrial activity by recording the contractions over a long five or ten minutes period and all scans were videotaped and analysed without knowledge of group at the end of the study. Also, only periods without interference of intestinal motility were used for evaluation.

Significant differences were seen in the uterine contractile activity of all mares between the different times of evaluation. Artificial insemination stimulated uterine contractions, which is in agreement with previous studies (Taverne et al. 1979, Madill et al. 2002, Campbell and England 2003). But as a new aspect it could be proven in the present study that a second insemination induces even stronger UCA than a single insemination, while score levels immediately before inseminations remained nearly the same. At the moment of the second insemination $48 \mathrm{~h}$ after hCG administration $63 \%$ of mares had already ovulated. Nevertheless they showed significantly stronger uterine contractions after insemination, although progesterone levels in the local blood supply should be already rising at this moment, and Evans et al. (1986) demonstrated that myometrial activity is low under progesterone influence. In a previous study on mares estrus cycles without inseminations Campbell and England (2002) recognized that uterine contractions were lowest on the day of ovulation and that no significant differences were present between the other days of the cycle. UCA associated with teasing was similar during the time period between two days before ovulation and the day of ovulation, while two days after ovulation teasing did not stimulate UCA anymore (Stecco et al. 2003). In the present study mares with a corpus hemorrhagicum at the time of the second insemination must have ovulated within the last $24 \mathrm{~h}$, because at the time of first insemination a dominant follicle was still present in all mares. UCA $48 \mathrm{~h}$ after the second insemination was also significantly stronger than UCA on day 16 to 18 of the cycle. A determination of progesterone plasma levels at the time of measurements of uterine contractions would have been helpful in the present study.

Fertile control mares had in general a stronger myometrial activity than the subfertile mares. Significant differences in UCA after the first and second insemination were found between the high activity groups (fertile control and oxytocin) and the low activity groups (seminal plasma and untreated), respectively. UCA of the seminal plasma treated group and the untreated group differed at no time significantly. These observations are supported by previous studies of Troedsson and Liu (1991) where subfertile mares susceptible for post breeding endometritis could not eleminate markers from the uterus as fast as fertile control mares, and LeBlanc (1997) or Cadario et al. (1999) who found that UCA could be stimulated in susceptible mares by oxytocin. Interestingly, in the present study, additional seminal plasma given into the uterus directly after insemination could not stimulate uterine contractions, similar to a study of Portus et al. (2005) where contractions even decreased, and as already reported by Pansegrau et al. (2006). Before, seminal plasma was supposed to have a stimulating effect on UCA because oxytocin and prostaglandins could be isolated from all fractions of the ejaculate (Watson et al. 1999). But highest levels of oxytocin were 
found in the gel fraction which is normally removed for artificial insemination. It is still not fully understood what causes the strong uterine contractions after insemination (Köllmann et al. 2005). Fuchs (1972) supposed a sympathical uterine reflex after mating for the rabbit, because an intravenous application of epinephrin caused similar contractions. Also Jones et al. (1991) assumed that the myometrial activity was not induced by hormones because it started too fast after breeding. Nikolakopoulos et al. (2000) showed that oxytocin plasma levels increased within 7 min after teasing or breeding in the mare. Also PGFM plasma levels were determined in mares susceptible and resistant to post breeding endometritis. Subfertile mares showed lower PGFM levels than fertile mares. Troedsson et al. (1998) recognized an initial increase in UCA for the first 30 min after insemination and a second increase for the period 4 to $12 \mathrm{~h}$ after insemination. Troedsson presumed that the first increase in uterine activity is oxytocin induced and the second period of contractions is mediated by uterine inflammation and therefore by increasing prostaglandin levels. If we suppose an initial sympathic reflex which is influenced by oxytocin as cause of the uterine contractions after insemination, seminal plasma would not be important for the myometrial activity, because the oxytocinrich gel fraction of the seminal plasma is removed during centrifugation of the semen. And also the uptake of the seminal plasma oxytocin by the endometrium might be too slow to play a role in initial uterine contractions after breeding.

In the present study UCA were correlated with pregnancy rates. Mares with increased uterine contractions had a better chance for a pregnancy. But pregnancy results differed significantly between the groups (control $83 \%$, oxytocin $33 \%$, seminal plasma $36 \%$ and untreated $50 \%$ ), and even though the oxytocin treated group showed good uterine contractions pregnancy results were low. Interpretation of this observation is difficult. Oxytocin was used in a number of species to improve conception rates. Rigby et al. (1999) tried this in mares, which were inseminated with semen of subfertile stallions (oxytocin injection given directly after insemination). Oxytocin had no significant effect on the pregnancy results in that study, although the oxytocin treated mares showed also lowest pregnancy rates. The authors proposed a precocious elimination of spermatozoa from the mare's uterus, because of the oxytocin induced increased uterine contractions. To find out if oxytocin, admistered directly after insemination, may have a negative effect on pregnancy rates because of precocious elimination of spermatozoa from the genital tract, two mares (a 4 years old maiden mare and a 16 years old subfertile barren mare) were inseminated with a defined sperm number during one estrus and treated with oxytocin directly after insemination. In the next estrus the animals were only inseminated but not treated with oxytocin. In each case sperm cells were counted following an uterine lavage two hours after insemination. These preliminary results indicate that oxytocin did not induce precocious sperm elimination. There were no sperm found in both uterine lavage fluids of the maiden mare. But the lavage fluid of the old subfertile mare showed both times, oxytocin treated or not, high sperm numbers $2 \mathrm{~h}$ after insemination. Sieme (pers. communication to S. Meinecke-Tillmann 2006) recognized that in mares, inseminated with $600 \times 10^{6}$ spermatozoa, 30 min after insemination less than $40 \%$ and $2 \mathrm{~h}$ after insemination less than $20 \%$ of the inseminated sperm cells could be recovered. This indicates that oxytocin caused an increase in UCA but did not cause precocious sperm elimination from the uterus in the subfertile mare and was presumably not the reason of the low pregnancy results in the oxytocin treated group.

Bacteriological and cytological samples obtained prior to the first and $48 \mathrm{~h}$ after the second insemination showed no significant differences in the total group of mares. Significantly less positive bacteriological samples were seen $48 \mathrm{~h}$ after the second insemination in the oxytocin group than in the seminal plasma treated group $(P=0.02)$. But in the oxytocin treated group bacterial counts were already low before insemination $(67 \%$ negative samples before $\mathrm{Al}$ vs. $74 \%$ negative samples $48 \mathrm{~h}$ after Al). There was no significant correlation between UCA and the results of the bacteriological and cytological samples of the endometrium. This confirms the results of Nikolakopoulos and Watson (1997), who demonstrated that uterine contractions contributed in elemination of fluids but not bacteria. The increase of negative bacteriological findings ( $42 \%$ to $75 \%$ negative) in the fertile control group of the present study is still interesting.

Cytological samples obtained $48 \mathrm{~h}$ after the second insemination showed no significant differences between the groups. The seminal plasma treated mares and the fertile control group showed lowest PMN counts. These results are similar to those from Maloufi et al. (2002) and Güvenc et al. (2004) where 24 and 96 hours after insemination with frozen semen no differences in PMN counts were found between subfertile and fertile mares. In the latter studies as well as in the present investigation the cytological samples were taken late after insemination. The samples obtained at that time may show the period of elimination of PMNs or a persisting endometrial inflammation, rather than the acute immune response. Already 30 min after insemination PMNs are found in the uterus and the acute post breeding inflammation peaks between 8 and 24 h while most of the PMNs are gone by $48 \mathrm{~h}$ (Katila 1995, 1997).

In the present study cytological samples obtained $48 \mathrm{~h}$ after the second insemination indicate a significant interrelationship to pregnancy results. $79 \%$ of the non pregnant mares showed postive cytological results $48 \mathrm{~h}$ after insemination, and $60 \%$ of the mares classified as pregnant showed no PMNs in the uterus at this time. Therefore cytological samples obtained $48 \mathrm{~h}$ after insemination are a good tool to predict the pregnancy result.

From the present study it can be concluded that the uterine contractile activity is stimulated following artificial insemination, and that consecutive inseminations lead to even stronger uterine contractions. Subfertile, barren mares showed a lower UCA than fertile mares. UCA could be enhanced by oxytocin in these barren mares but not by seminal plasma. Despite the low pregnancy rates in the oxytocin-treated mares, the experiment indicates, that oxytocin-administration after insemination did not cause precocious elimination of spermatozoa from the mare's uterus. Because of the positive correlation between UCA and the pregnancy rate, poor uterine contractions are verified as one major cause of subfertility in mares. For obtaining high conception rates negative cytological swabs $48 \mathrm{~h}$ after insemination are indicative, since mares with positive results at this time had a minor chance of getting pregnant. Enhancement of UCA by optimal inse- 
mination frequency and time of uterine sampling should be discussed in the management of broodmares.

\section{Manufacturer's addresses}

1 Oxytocin Bengen, WDT, Garbsen, Germany

2 Ovogest 5000, Intervet, Unterschleissheim, Germany

3 Falco 100, Pie Medical, Dorsten, Germany

4 Equivet, Kruuse UK Ltd, Sherburn Elmet, UK

5 Oxoid, Basingstoke, UK

6 SPSS, Chicago, USA

7 SAS, Cary, USA

\section{References}

Bader H. (1982) An investigation of sperm migration into the oviducts of the mare. J. Reprod. Fert. Suppl. 32, 59-64

Brook D. (1984) The diagnosis of equine bacterial endometritis. Comp. Contin. Educ. Pract. Vet. 6, 300-306

Busch W. and Klug E. (1999) Erkrankungen des Uterus. In: O. Dietz, B. Huskamp (Ed.). Handbuch Pferdepraxis 2nd ed., Enke, Stuttgart, 588-595

Cadario M. E., Merritt A. M., Archbald L. F., Thatcher W. W. and LeBlanc M. M. (1999) Changes in intrauterine pressure after oxytocin administration in reproductively normal mares and in those with a delay in uterine clearence. Theriogenology 51, 1017-1025

Campbell M. L. H. and England G. C. W. (2002) M-mode ultrasound imaging of the contractions of the equine uterus. Vet. Rec. $150,575-577$

Campbell M. L. H. and England G. C. W. (2003) The effect of coitus and of artificial insemination on uterine contractions in mares: a review. Ippologia 14 (1), 3-8

Campbell M. L. H. and England G. C. W. (2004) Effect of teasing, mechanical stimulation and the intrauterine infusion of saline on uterine contractions in mares. Vet. Rec. 155, 103-110

Campbell M. L. H. and England G. C. W. (2006) The effect of coitus and artificial insemination of different volumes of fresh semen on uterine contractions in the mare. Anim. Reprod. Sci. 94, 248-251

Cross D. T. and Ginther O. J. (1988) Uterine contractions in nonpregnant and early pregnant mares and jennies as determined by ultrasonography. J. Anim. Sci. 66, 250-254

Dahms B. J. and Troedsson M. H. T. (2002) The effect of seminal plasma components on opsonisation and PMN-phagozytosis of equine spermatozoa. Theriogenology 58, 457-460

Evans M. J., Hamer J. M., Gascon L. M., Graham C. S., Asbury A. C. and Irvine C. H. G. (1986) Clearance of bacteria and non-antigenic markers following intra-uterine inoculation into maiden mares: effect of steroid hormone environment. Theriogenology 26, 37-49

Fiala S. M., Pimentel C. A., Steiger K., Mattos A. L. G., Gregory R. M. and Mattos R. C. (2002) Effect of skim milk and seminal plasma uterine infusions in mares. Theriogenology 58, 491-494

Fuchs A.-R. (1972) Uterine activity during and after mating in the rabbit. Fertil. Steril. 23, 915-923

Gibbs H. M. and Troedsson M. H. T. (1995) Effect of acepromazine, detomidine, and xylazine on myometrial activity in the mare. Biol. Reprod. Mono. 1, 489-493

Griffin P. G. and Ginther O. J. (1990) Uterine contractile activity in mares during the estrus cycle and early pregnancy. Theriogenology $34,47-56$

Griffin P. G. and Ginther O. J. (1993) Effects of day of estrus cycle, time of day, luteolysis, and embryo on uterine contractility in mares. Theriogenology 39, 997-1008

Griffin P. G., Hermenet M. J. and Ginther O. J. (1992) A transient increase in uterine tone during early diestrus in mares. Theriogenology 37, $1185-1190$

Güvenc K., Reilas T. and Katila T. (2004) Effect of frozen semen on the uterus of mares with pathological uterine changes. Reprod. Nutr. Dev. 44, 243-250
Haluska G. J., Lowe J. E. and Currie W. B. (1987) Electromyographic properties of the myometrium correlated with the endocrinology of the pre-partum and post-partum periods and parturtition in pony mares. J. Reprod. Fertil. Suppl. 35, 553-564

Jones D. M., Fielden E. D. and Carr D. H. (1991) Some physiological and pharmacological factors affecting uterine motility as measured by electromyography in the mare. J. Reprod. Fert. Suppl. 44, 357-368

Katila T. (1995) Onset and duration of uterine inflammatory response of mares after insemination with fresh semen. Biol. Reprod. Mono. 1, 515-517

Katila T. (1997) Interaktionen zwischen Uterus und Samen. Pferdeheilkunde 13, 508-511

Katila T., Sankari S. and Mäkela O. (2000) Transport of spermatozoa in the reproductive tracts of mares. J. Reprod. Fert. Suppl. 56, $571-578$

Kenney R. M. and Doig P. A. (1986) Equine endometrial biopsy. In Morrow, D. A. (Ed.). Current therapy in theriogenology 2. W. B. Saunders, Comp., Philadelphia, 723-729

Köllmann M. C., Meinecke-Tillmann S., Swagemakers J.-H. and Meinecke B. (2005) Influence of cryopreserved sperm or semen extender on uterine contractile activity in mares following conventional or hysteroscopic insemination. Anim. Reprod. Sci. 89, 206-208

Kotilainen T., Huhtinen M. and Katila T. (1994) Sperm-induced leukocytosis in the equine uterus. Theriogenology 41, 629-636

LeBlanc M. M. (1997) Die Wirkung von Oxyłocin, Prostaglandin und Phenylbutazon auf die uterine Clearance von Radiokolloiden. Pferdeheilkunde 13, 483-485

Leith G. S. and Ginther O. J. (1985) Mobility of the conceptus and uterine contractions in the mare. Theriogenology 24, 701-711

Madill S., Troedsson M. H. T., Santschi E. M. and Malone E. D. (2002) Dose-response effect of intramuscular oxytocin treatment on myometrial contraction of reproductively normal mares during estrus. Theriogenology 58, 479-481

Maloufi F., Pierson R., Otto S., Ball C. and Card C. (2002) Mares susceptible or resistant to endometritis have similar endometrial echographic and inflammatory cell reactions at 96 hours after infustion with frozen semen and extender. In: Proc. of the 48th Ann. Meet. AAEP 2002, Orlando,USA, AAEP (Ed.) 48, 51-57

Nikolakopoulos E., Kindahl H. and Watson E. D. (2000) Oxytocin and PGF2 $\alpha$ release in mares resistant and susceptible to persistent mating-induced endometritis. J. Reprod. Fertil. Suppl. 56, 363-372

Nikolakopoulos E. and Watson E. D. (1997) Uterine motility in mares resistant and susceptible to endometritis. J. Reprod. Fertil. Abstr. Ser. 20, 14

Nikolakopoulos E. and Watson E. D. (2002) Can uterine contractile activity be evaluated by transrectal ultrasonography? Theriogenology 58, 483-486

Palm F., Walter I., Budik S. and Aurich C. (2006) Influence of different semen extenders and seminal plasma on the inflammatory response of the endometrium in oestrus mares. Anim. Reprod. Sci. 94, 286-289

Pansegrau U., Meinecke-Tillmann S., Swagemakers J.-H. and Meinecke B. (2006) Clinical investigation for a prospective classification of subfertile mares under field conditions. Reprod. Domest. Anim. Vol. 41 Suppl. 1, 89 abstract

Portus B., Reilas J. T. and Katila T. (2005) Effect of seminal plasma on uterine inflammation, contractility and pregnancy rates in mares. Equine Vet. J. 37, 515-519

Quetin M. (2001) Klinisch-gynäkologische und histopathologische Untersuchungen zur Beurteilung der endometrialen Reaktion auf besamungsrelevante Medien (Samenverdünner, Seminalplasma, Spermien) bei Warmblutstuten. Diss. Med. Vet. Hannover

Rigby S., Hill J., Miller C., Thompson J., Varner D. and Blanchard T. (1999) Administration of oxytocin immediately after insemination does not improve pregnancy rates in mares bred by fertile or subfertile stallions. Theriogenology 51, 1143-1150

Schatzmann U., Josseck H., Stauffer J.-L. and Goossens L. (1994) Effects of alpha2-agonists on intrauterine pressure and sedation in horses: Comparison between detomidine, romifidine and xylazine. J. Vet. Med. A. 41, 523-529

Sinnemaa L., Järvimaa T., Lehmonen N., Mäkela O., Sankari S. and Katila T. (2005) Effect of insemination volume on uterine contractions and inflammatory response and on elimination of semen in the mare uterus - scintigraphic and ultrasonographic studies. J. Vet. Med. A. 52, 466-471 
Stecco R., Paccamonti D., Gutjahr S., Pinto C. R. F. and Eilts B. (2003) Day of cycle affects changes in equine intrauterine pressure in response to teasing. Theriogenology 60, 727-733

Taverne M. A. M., van der Weyden C. G., Fontijne P., Dieleman S. J., Pashen R. L. and Allen W. R. (1979) In-vivo myometrial electrical activity in the cyclic mare. J. Reprod. Fert. 56, 521-532

Troedsson M. H. T. and Liu I. K. M. (1991) Uterine clearance of nonantigenic markers $\left({ }^{51} \mathrm{Cr}\right)$ in response to a bacterial challenge in mares potentially susceptible and resistant to chronic uterine infections. J. Reprod. Fert. Suppl. 44, 283-288

Troedsson M. H. T., Crabo B. G., Ibrahim N., Scott M. and Ing M. (1995) Mating-induced endometritis: mechanisms, clinical importance, and consequences. In: Proc. of the 41 th Ann. Meet. AAEP, Lexington, USA, AAEP (Ed.) 41, 11-12
Troedsson M. H. T., Liu I. K. M. and Crabo B. G. (1998) Sperm transport and survival in the mare: A review. Theriogenology 50, 807-818 Watson E. D., Nikolakopoulos E., Gilbert C. and Goode J. (1999) Oxytocin in the semen and gonads of the stallion. Theriogenology $51,855-865$

Prof. Dr. Sabine Meinecke-Tillmann Institut für Reproduktionsbiologie Tierärztliche Hochschule Hannover Bünteweg 2 30559 Hannover

sabine.meinecke-tillmann@tiho-hannover.de 